\title{
A GM subsistence crop in Africa: the case of Bt white maize in South Africa
}

\author{
Marnus Gouse, Carl E. Pray, Johann Kirsten and \\ David Schimmelpfennig
}

\section{Introduction}

A major complaint of both the critics and some supporters of biotechnology is that biotechnology companies have not produced any Genetically Modified (GM) crops that will directly increase production of the basic subsistence foods in developing countries or increase the income of the small farmers who produce these crops. GM maize in the Republic of South Africa (RSA) is the exception to this generalisation, and could be an important proving ground for GM food crops for Africa and rest of the developing world. RSA is the only developing country in which GM varieties of the basic staple food crop are grown. The basic staple food of South Africans is white-grained maize. Yellow-grained maize is also grown in large quantities, but is primarily used as animal feed and as an input in the food industry in RSA. In 1998, maize hybrids, which were modified to include a Bacillus thuringiensis $(\mathrm{Bt})$ gene $^{1}$ to make them resistant to the maize stem borer, were approved for commercial use by the government. The first Bt maize hybrids were yellow grained. In 2001, seed companies had developed and started selling white-grained Bt maize hybrids.

If GM white and yellow maize proves to be beneficial to small farmers and poor consumers in RSA, the rest of Africa may be more likely to adopt GM food crops. Bt white maize has the potential to substantially increase yields, to increase income for farm families, to reduce pesticide use, and to improve the health of the rural poor by reducing their exposure to mycotoxins in maize. This paper presents the preliminary results of surveys of large-scale farmers who produce yellow maize and small-scale (in most cases subsistence) farmers who produce white maize. These results indicate the potential for both types of farmers and consumers to benefit from this technology. The first section of the paper presents the history of the development and spread of Bt maize in RSA. Section 2 will address the impact of $\mathrm{Bt}$ maize on large-scale, commercial farms in the country. Section 3 reviews the findings about Bt maize production by the small-scale subsistence farmer and the last section, Section 4, focuses on ways in which seed companies and the government could increase the benefits from Bt maize for small farmers in RSA.

\section{The development and spread of Bt Maize}

Research on medical and agricultural biotechnology in South Africa started in the late 1970s. The first experimental plantings of GM plants in 1990 were USA cotton varieties with $\mathrm{Bt}$ genes. In 1997, Bt cotton was approved by the RSA Government for commercial planting, and 1997/98 was the first growing season for this crop. One year later in 1998, Bt maize, which is resistant to stem borer, became the second GM crop approved for commercial use. Bt yellow maize was planted in the 1998/99 cropping season. Research on genes and varieties conducted in USA by multinational biotech company Monsanto also produced Herbicide Tolerant (HT) soybeans, cotton and maize and cotton varieties that had both Bt and HT genes. In addition, two other biotech multinationals, Syngenta and Dow Chemicals, have also developed different Bt genes that provide protection against insects.

In South Africa and other Southern African countries the losses sustained in maize crops due to damage caused by the African maize stem borer (Busseola fusca,) are estimated to be between 5 and $75 \%$; and, it is generally accepted that $B$. fusca reduces the South African maize crop by an average of 10\% (Annecke and Moran, 1982) Accordingly, Busseola fusca and the Chilo stem borer (Chilo partellus) are the most harmful pests of 
maize and grain sorghum in South Africa. (Kfir, 1997) A seemingly conservative estimation of $10 \%$ for damage caused by both $B$. fusca and C. partellus means an average annual loss of just under a million tonnes of maize with an approximate value of R810 million. According to unpublished 'Crop production guidelines' of the South African Department of Agriculture in 1991, it is especially the November plantings on the Highveld that four in every five seasons come under considerable pressure from second generation stem borers known as 'kopruspe', (Department of Agriculture, 1991) .

Monsanto tested the Bt gene, CrylAc, which controls European stem borer in the USA, and found that it gives satisfactory control over the local RSA borers. The RSA biosafety committee approved maize containing Cry1 Ac in 1998 and commercialised it in the same year in yellow maize hybrids. Under the South African biosafety rules, once a gene in a specific variety has been approved, that gene can then be backcrossed into other varieties of the same crop without further regulatory approval by the government. The biosafety committee approved no new genes for maize until 2003. In that year RSA approved Syngenta's Bt maize, breaking Monsanto's monopoly on Bt genes in RSA. In addition, the biosafety committee approved GM maize that is resistant to Monsanto's herbicide Round-up.

Monsanto not only sells its Bt gene in its own hybrids but also licenses this gene to the companies Pioneer and Pannar, for use in their hybrids (Table 1).

Table 1

GM maize sources of genes and hybrids

\begin{tabular}{ccccc}
\hline & $\begin{array}{c}\text { Source of } \\
\text { Gene }\end{array}$ & \multicolumn{1}{c}{$\begin{array}{c}\text { Source of } \\
\text { Hybrids }\end{array}$} & $\begin{array}{c}\text { Year Gene Approved } \\
\text { for Commercial Use }\end{array}$ & $\begin{array}{c}\text { First Year } \\
\text { Planting }\end{array}$ \\
\hline Bt Yellow Maize & Monsanto & Monsanto & 1998 & 1998 \\
& Monsanto & Pioneer & 1998 & 1999 \\
& Monsanto & Pannar & 1998 & 1999 \\
& Syngenta & Syngenta & 2003 & 2003 \\
& Dow & Pioneer & future & 2003 (not \\
RR Yellow Maize & Monsanto & Monsanto & 2003 & for sale yet) \\
& & & 1998 & 2001 \\
Bt White Maize & Monsanto & Monsanto & 1998 & 2001 \\
& Monsanto & Pioneer & 1998 & 2004 \\
& Monsanto & Pannar & 2003 & 2003 (not \\
\hline
\end{tabular}

Source: Interviews with seed companies, August 2003.

Those companies have back-crossed CrylAc into their hybrids. Monsanto sells the Bt seed primarily to large-scale commercial farmers, but reserves a small amount of seed each year for sales to small-scale farmers. Pioneer and Pannar sell their seed to the large-scale commercial farmers. Pannar is the only company that has a specific maize breeding programme for small-scale producers, but it has not introduced $\mathrm{Bt}$ in its hybrids for small-scale farmers. Syngenta sells its Bt to large farmers through Syngenta-Seedco, a joint venture between Syngenta and the seed company Seedco (Zimbabwe). Seedco has strong sales of conventional white hybrids to the small farmers in Zimbabwe and these same hybrids may in the future, contain Syngenta's $\mathrm{Bt}$ in them as they expand in the region. Dow Chemicals has been testing its $\mathrm{Bt}$ in Pioneer maize in RSA and their Bt maize is likely to be approved in the next year or so.

The initial spread of Bt maize was quite slow. In 2000/2001 after two years of experience with Bt maize, farmers planted between 75,000 and 100,000 ha of Bt maize or less that $3 \%$ of the total maize area (Table 2). Seed companies and farmers suggested three main factors were responsible for the slow spread of Bt maize. First, the Bt hybrids that were on the market were not well-adapted to the local South 
African consumer markets, or for local agricultural conditions. White maize is usually planted on $50-60 \%$ of the maize area, but Bt white maize hybrids were not for sale to farmers until 2001. The yellow maize varieties that were available were not the ideal hybrids for the region; one company reported that the first $\mathrm{Bt}$ maize seed sold was a hybrid developed for the American Corn Belt. To be successful, this variety had to be grown in one of RSA's small irrigated maize regions.

Table 2

Estimated area planted to transgenic crops

\begin{tabular}{lrrrr}
\hline Crop & $1999 / 2000$ & $2000 / 2001$ & $2001 / 2002$ & $2002 / 2003$ \\
\hline Bt Yellow Maize ha & 50000 & 75000 & 160000 & 197000 \\
$\%$ of yellow & 3 & 5 & 14 & 20 \\
Bt White Maize ha & 0 & 0 & 6000 & 55000 \\
$\%$ of white & 0 & 0 & 0.4 & 2.8 \\
Total Bt Maize ha & 50000 & 75000 & 166000 & 252000 \\
$\%$ of total & 1.3 & 2.3 & 4.7 & 7.1 \\
\hline
\end{tabular}

Source: SANSOR and Monsanto

A second reason for slow adoption was that many farmers did not see a big productivity advantage from the Bt gene. Stem borer is the main problem that Bt maize solves. Many farmers find that if they manage to plant at the recommended time, they will miss the first moth flight and have limited damage whether they plant Bt varieties or not. In addition, many large farmers felt that the increased yield from Bt maize was not enough to pay for the company's technology fee. Thus, at first Bt probably was adopted only in those places where stem borer was a particularly difficult problem.

The third reason for the slow spread of Bt maize was the farmers' concerns that they would not be able to sell their crop because of consumer concerns about GM food.

More appropriate Bt maize hybrids finally became available in 2000 and 2001. Firms started selling Bt yellow maize hybrids that were specifically developed for South Africa's dry windy conditions in 2000. In 2001, the first Bt white maize hybrids were released. The second constraint - farmers' perception of low profitability - changed in 2001/02 season. That season was affected by a particularly severe attack of stem borers and commercial farmers suffered high rates of damage and yield losses due to borers. As a result many more commercial farmers opted to use Bt maize in the 2002/03 planting season. The final constraint - farmers' concern about demand and consumer acceptance - has not proved to be a major problem so far. While several African countries will not import animal feed with GM ingredients and Zambia had outrightly rejected US food aid because it contained GM maize, there is currently no price premium for non-GM maize accruing to the farmers in RSA, and farmers are not having any difficulty selling their GM crops.

In the 2002/3 planting season, there had been an increase in adoption of GM maize as evidenced by the increase in acreage planted (Table 2). Seed firms estimated that the area could easily double the current level to 5-600,000 ha in 2003/4. The main constraint appeared to be the supply of seed, particularly Bt white maize seed, which had not kept up with the growth of demand.

Small-scale farmers were able to obtain Bt white maize seed for the first time in 2001/02. Small-scale farmers in nine areas of Mpumalanga, KwaZulu Natal, Eastern Cape, and Limpopo, were given small packets of white Bt maize and the isoline (the same hybrid which does not include Bt). In 2002/03, many small-scale farmers tried to buy Bt maize seed, but due to a limited seed supply and the increased demand by large-scale farmers, not many small-scale farmers were able to obtain Bt seed.

\section{Impact of Bt Maize on large-scale farmers}

Did the adoption of $\mathrm{Bt}$ maize really have a measurable impact on farmers' yields and pesticide use? As mentioned above, the main target of Bt maize in SA is the African maize 
stem borer (Busseola fusca) and the Chilo borer (Chilo partellus); they are estimated to be annually responsible for more than $10 \%$ maize yield loss even though chemicals are used to control them. A 10\% yield loss means an average annual loss of just under a million tonnes with an approximate value of US\$ 116 million. However, in the US where Bt was supposed to control similar pests, farmers did not achieve the expected gains in benefits. Surveys of US farmers show that benefits from Bt maize were a small increase in yields but little reduction in insecticide use. Adoption of Bt corn did not reduce pesticide use because in most areas and over most years, the European corn borer infestation level is low and pesticides are not very effective so that few farmers used pesticides on their conventional maize hybrids (Marra, Pardey and Alston, 2002).

\subsection{Methodology}

The data that serves as the basis for our preliminary assessment of the impacts of GM maize in RSA were from a sample of 33 large-scale maize producers. They were surveyed to collect production data for the 1999/2000 and 2000/2001 production seasons. Due to the small number of farmers planting Bt maize at the time, farmers were identified with the help of Pioneer seed company and seed agents working in the various areas. All except one of the farmers, grew both $\mathrm{Bt}$ and conventional maize. The irrigated farms in the sample were from the Northern Cape and Mpumalanga, and the dry land sample consisted of farmers in Mpumalanga and the North West Provinces. In most seasons less than $10 \%$ of RSA maize area is irrigated. The Department of Agricultural Economics, Extension and Rural Development of the University of Pretoria, sent out a mail survey after the 2000/2001 season, but only a limited number of farmers replied. The rest of the data were gathered by visiting the farms and filling in the questionnaires with the farmers directly.

\subsection{Results}

The yield advantages enjoyed by large-scale yellow maize farmers who adopted $\mathrm{Bt}$ maize are indicated in Table 3 . The $1200 \mathrm{~kg} / \mathrm{ha}$ and $326 \mathrm{~kg} / \mathrm{ha}$ yield advantage is an 11.03 and $10.60 \%$ yield increase on irrigated farms and dry land, respectively. It is important to note that the differences in means of $\mathrm{Bt}$ and conventional hybrids were statistically significant (at the 5\% level) only in the total irrigation and the total dry land calculations. Given these figures, it is safe to deduce that large-scale, yellow maize farmers were able to increase their yields with Bt maize. Farmers did not report a high level of stem borer infestation in either season or survey region. The yield benefits would increase in seasons with higher stem borer pressure.

Table 3

Average maize yields for Bt and conventional hybrids 2000/1 and 2001/2

\begin{tabular}{llrrr}
\hline Province & Conditions & \multicolumn{1}{l}{$\begin{array}{l}\text { Yield with Bt } \\
\text { Maize }\end{array}$} & $\begin{array}{l}\text { Yield with } \\
\text { Conventional Maize }\end{array}$ & $\begin{array}{l}\text { \% yield } \\
\text { Advantage }\end{array}$ \\
\hline Mpumalanga & Irrigation & 11280 & 10500 & $7 \%$ \\
Northern Cape & Irrigation & 12160 & 10860 & $12 \%$ \\
Total & Irrigation & $12081^{*}$ & $10881^{*}$ & $11.03 \%$ \\
Mpumalanga & Dry land & 5000 & 4500 & $11 \%$ \\
North West & Dry land & 3130 & 2920 & $7 \%$ \\
Total & Dry land & $3398^{*}$ & $3072^{*}$ & $10.60 \%$ \\
\hline
\end{tabular}

Note: * Means statistically different

Source: Author's survey

In addition to the yield gains from Bt yellow maize, large-scale farmers were also able to save on their plant protection operations. $70 \%$ of the large-scale yellow maize farmers in our survey indicated stem borers to be the dominant insect problem in maize production and, unlike USA, farmers seem to have sprayed substantial amounts of pesticide to control them - particularly in the irrigated areas. The 
reduction in pesticide cost measured in Table 4 is only part of the farmers' actual reduction in pest management costs. Other savings come in the form of lower costs of labour and fuel in the application process and less time spent scouting fields for pest build up. As we expected, the reductions in costs were highest in the irrigated regions where moist conditions are more favourable to insect growth and reproduction.

Table 4

Large-scale farmers' costs of applied pesticides

\begin{tabular}{lccc}
\hline & & $\begin{array}{c}\text { Insecticide Cost with } \\
\text { Conventional Maize (US\$/ha) }\end{array}$ & $\begin{array}{c}\text { Insecticide Cost with } \\
\text { Bt Maize (US\$/ha) }\end{array}$ \\
\hline Northern Cape & Irrigation & 25.4 & 10.4 \\
Mpumalanga & Irrigation & 32.14 & 11.4 \\
Mpumalanga & Dry land & 13.3 & 6.57 \\
North West & Dry land & 9.7 & 1.9 \\
\hline
\end{tabular}

Source: Author's survey

Large-scale farmers who planted Bt yellow maize enjoyed an increased income on their $\mathrm{Bt}$ maize fields compared to their conventional maize fields, despite paying a technology fee along with the seed price (Table 5). They received the same price for their Bt maize and their conventional maize so the difference in revenue was directly due to the yield increase. They were able to reduce their costs by reducing the amount of pesticide applied, but these gains were partially offset by the technology fee for Bt that is paid when seeds are purchased. The price difference between conventional yellow maize seed and Bt maize seed (plus technology fee) varied between the different seed companies. For example, the price difference in 2000/2001, typically ranged between US\$19 for a bag of 80,000 seeds to US $\$ 31$ for a bag of 60,000 seeds. The increase in net income ranged from US\$ 24 per ha in dry land areas to over a thousand Rand (US\$143) per ha in the Northern Cape irrigated regions.

Table 5

Income effect of adoption of Bt yellow maize

\begin{tabular}{|c|c|c|c|c|}
\hline & $\begin{array}{l}\text { Mpumalanga } \\
\text { Dry land } \\
\text { (US\$/ha) }\end{array}$ & $\begin{array}{l}\text { North West } \\
\text { Dry land } \\
\text { (US\$/ha) }\end{array}$ & \multirow{2}{*}{$\begin{array}{l}\text { Mpumalanga } \\
\text { Irrigation } \\
\text { (US\$/ha) } \\
24\end{array}$} & $\begin{array}{l}\text { Northern Cape } \\
\text { Irrigation } \\
\text { (US\$/ha) }\end{array}$ \\
\hline $\begin{array}{l}\text { Yield Benefits per hectare } \\
\text { US\$114/ton }\end{array}$ & 57 & 24 & & 149 \\
\hline Reduced pesticides benefit & 7 & 8 & 21 & 15 \\
\hline $\begin{array}{l}\text { Increased seed cost } \\
\text { detriment* }\end{array}$ & 17 & 8 & 25 & 14 \\
\hline $\begin{array}{l}\text { Income advantage / } \\
\text { disadvantage }\end{array}$ & 47 & 24 & 85 & 149 \\
\hline
\end{tabular}

Note: *As indicated by surveyed farmers in different provinces

Source: Author's survey

\section{Can small-scale farmers also benefit?}

It seems clear that South African commercial farmers are adopting Bt maize and that largescale farmers are benefiting from its production. However, the question that makes the South African maize story of most interest to people who are working in the economic and social development of Africa and in other less developed countries, is whether small-scale farmers can benefit when $\mathrm{Bt}$ is incorporated into a subsistence crop such as white maize.

We have analysed farm level data from the 2001/02 planting season in six areas where Monsanto distributed white Bt and non-Bt maize seed free of charge. Monsanto worked with local extension agents and provided a two-day training programme to farmers 
selected by the extension system. Monsanto provided small packets of Bt hybrid seed and the isoline and asked farmers to plant these seeds next to their usual maize seed in their usual maize fields. Farmers were requested to keep the different varieties separate in planting and in harvest so that agronomic practices and impact of weather would be comparable throughout the season, and at the end of the production season the yields of the different hybrids could be measured.

\subsection{Methodology}

The small-scale farmers selected for this survey by the local extension officers and enumerators were from six of the nine sites in which Monsanto gave out free seed samples in 2001. The sample sizes in each site were calculated so as to be significant and representative of the population that received the maize seeds from Monsanto. The Department of Agricultural Economics, Extension and Rural Development of the University of Pretoria, with help from government extension officers, surveyed 368 farmers in the six selected sites. Potential enumerators from the specific areas were identified by extension officers and trained by University staff to collect the necessary data from the small-scale farmers. The survey was conducted from April 15 until June 21, 2002 and a university staff member was present at the various sites for the duration of the survey.

After an initial analysis of the data, we decided to express yields in kilograms of production per seed planted, rather than per hectare because of difficulties estimating both the output and area planted. The survey used farmer recall to obtain data on yields, area, and plant populations. Since their answers to the yield per ha and plant population per ha questions varied so greatly, it was felt that it would be more reliable to base the report on the output per quantity of seed planted. Farmers did have a fairly good idea of their total output of each type of hybrid, and the amount of Bt seed and the isoline seed planted could be verified by Monsanto's distribution programme. Thus, we thought that output per quantity of seed would be more accurate than output per hectare. In subsequent years we will measure by the quantity harvested and area sown, rather than rely on farmers' recall.

\subsection{Results}

The evidence from the experience of these farmers suggests that Bt maize has potential benefits for small-scale farmers. The evidence from this survey suggests that Bt maize has a large yield advantage over conventional hybrids (Figure 1). In Venda (Limpopo Province), Northern Highveld (Mpumalanga), and Hlabisa (KwaZulu Natal), the Bt seed, Yieldgard, gives substantial yield gains over the isoline. Yields were expressed in kilograms of production per seed planted (not per hectare).

The small-scale farmers were able to reduce pesticide costs in most areas, except Venda where very little pesticide was used in this particular season. About half of the farmers surveyed used insecticides (in granular form) intermittently. They reported that the main pest was indeed the stalk borer followed by cutworm. Less than $5 \%$ used pesticide on their Yieldgard maize plants. In most cases the farmers who did apply granules were not able to indicate how much insecticide was applied on their own maize, and how much on the free conventional maize. Since small-scale farmers received seed for free in this year and it proved difficult to obtain information from farmers on the precise estimates of pesticide use by the three different cultivators, it is not possible to calculate the potential change in a farmer's net income due to the adoption of Bt maize.

Another important finding of the survey was that the small-scale farmers also liked the quality of the maize produced by Yieldgard. At harvest, farmers were shown their own seed, CRN seed and the Yieldgard seed and asked to judge the grain according to quality. The majority of farmers rated the Yieldgard grain to be of excellent quality while many farmers rated the grain of the $\mathrm{CRN}$ and their local seed as good quality. The Bt maize had less pest damage on the grain than the others. When asked what they liked best about the $\mathrm{Bt}$ hybrid maize, farmers at three sites chose better quality, while higher yield was the most important reason at the other three sites. The farmers did not put much importance on the benefits from pesticide reduction (probably because only half of them used pesticides). 
Figure 1 Small farmers' yields per kg of seed, by seed type for each site 2001/2 Source: Author's survey

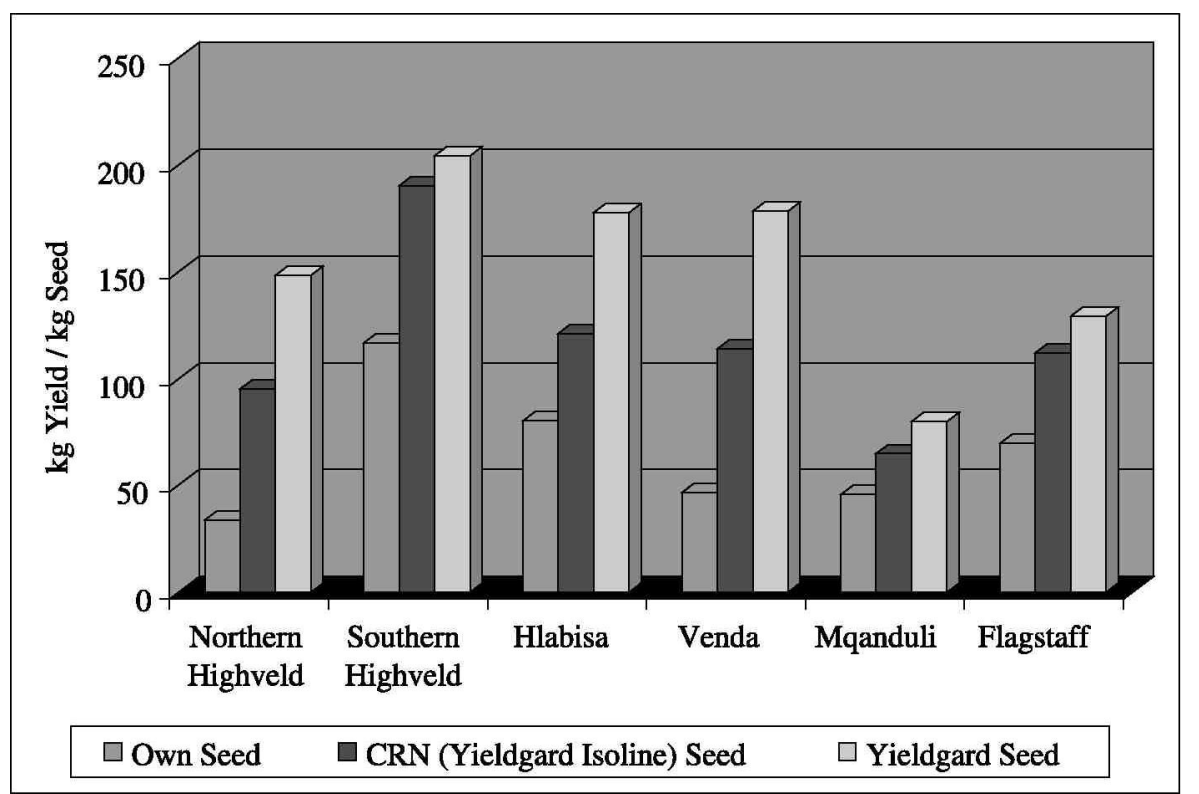

\section{How can small farmers benefit from Bt white Maize?}

The evidence from the large-scale farmers indicates that $\mathrm{Bt}$ maize can increase yields, reduce pesticide use and give farmers substantial economic benefits. The preliminary evidence from small-scale farmers also indicates that Bt maize can increase yields and reduce pesticide use. Unfortunately, we do not yet have enough information to assess whether net income will increase when farmers have to pay the market price for the seed. It seems likely that the small farmers who will purchase hybrid $\mathrm{Bt}$ maize are those that are already convinced of the value of buying hybrids. At present, officials at Pannar seed company estimate that about $10 \%$ of small-scale farmers plant their land with hybrids, primarily Pannar hybrids, while $90 \%$ of the small farmers' land is planted with open pollinated varieties (OPVs) and saved seeds of hybrids and OPVs. ${ }^{2}$ In our sample, in the Eastern Cape (Flagstaff and Mqanduli), farmers purchased very little seed, while in the rest of the survey sites the majority of farmers purchased hybrids or OPVs. Thus, it is likely that initial adoption would be limited to areas already growing hybrids and that there would be a much slower adoption of Bt hybrids in the poor areas like the Eastern Cape.

How can Bt maize cultivation spread to a larger share of the small farmers in RSA? The area under Bt maize could be expanded if companies are willing to segment the Bt maize seed market and charge a lower price to small farmers than they are currently charging to large farmers. Pannar currently has such a programme with the conventional hybrid maize seed. For small farmers, Pannar produces types of hybrid seeds (double-cross hybrids) or OPVs that are inexpensive seeds to produce, and it sells them at low prices $(\$ 50 / \mathrm{bag}$ for double-cross hybrids and $\$ 24 /$ bag for OPVs). At the same time it produces high cost types of hybrids (single cross hybrids) and charges premium prices $(\$ 100 / \mathrm{bag})$ to large commercial farmers. ${ }^{2}$ The government is putting pressure on agribusiness to do more to help smallholders and this is one way in which the seed companies could do that.

This type of pricing may not be possible if the biosafety regulatory process is structured so that it is more expensive for companies to provide technology to small-scale producers than to large-scale producers. Under the current system every farmer who plants Bt crop must sign a contract with the companies that are selling GM seeds to ensure that the farmer plants the seed where he says he will plant it, and abides by the proper refuge requirements. ${ }^{3}$ This is relatively easy for large companies who are selling directly through their marketing agents to large producers. However, this is an expensive requirement when companies are dealing with thousands of small farmers and could very well lead to a decision not to sell GM seeds to the smaller subsistence farmer at all.

Another way to encourage small farmers to adopt Bt maize would be for private firms or 
government research institutes to put Bt into maize OPVs. Then small farmers could save their seed and still get the benefit of the Bt. The downside of this scenario is that it would be almost impossible for the government to enforce any type of Bt maize refuge because they could not keep track of the farmer-to-farmer sale of Bt maize. Whether this would increase the speed at which Bt-resistant stem borers would develop is not known, but it certainly is a possibility. Thus, until we know more about the development of resistance, this possibility is probably not a realistic option.

Another way to improve the acceptance of Bt maize would be to utilise government subsidies to reduce the seed prices and the technology fee for the poorer farmer or provide subsidised credit to buy seed. The experience of Bt cotton in Makhathini suggests that credit, which has been subsidised from time to time by various government banks to purchase $\mathrm{Bt}$ seeds and complementary inputs, can be an important determinant of adoption of Bt crops by the poor, small-scale farmer. Seeds, pesticides, and other inputs were provided by a cooperative, which then purchased the crop and kept enough money from the sale of the cotton to pay for the value of the inputs. This allowed small-scale farmers to adopt $\mathrm{Bt}$ cotton very rapidly. However, on the Makhathini Flats in recent years, when farmers were not able to get credit, the area under $\mathrm{Bt}$ and conventional cotton dropped dramatically. Agricultural scientists who are active on the Makhathini Flats report that the farmers who planted self-financed cotton all planted Bt cotton (Hofs, 2003) .

The evidence in this paper suggests that $\mathrm{Bt}$ white maize can be beneficial in Africa because it can substantially increase crop yields and reduce pesticide use. This could increase small farmer's incomes if the Bt maize seed cost is not too high. If Bt maize does turn out to be profitable for small farmers in RSA, farmers who already use hybrids will adopt it quickly not only in RSA but also elsewhere in Africa. In Zimbabwe, 91\% of the maize area was planted with hybrids in 1997-99. In Kenya, $85 \%$ of the maize area was hybrids, and in Zambia, 65\% was hybrids (Aquino et al., 2001). The key will be whether African countries can put in place credible biosafety regulatory systems, and African politicians are able to base their decisions about GM crops on scientific evidence of the risks, costs and benefits of these technologies.

\section{Acknowledgements}

This work is supported by grants from the Rockefeller Foundation and Monsanto Corporation. We thank participants in the mini-symposium 'Biotechnology in Developing Countries' at the 25th triennial meeting of the International Association of Agricultural Economists in Durban, South Africa, August 16-22, 2003 for many comments. The views expressed in this article are not necessarily those of the US Department of Agriculture. We would also like to thank Sheilah M. Louis for her editorial help.

\section{References}

Annecke, D.P. and Moran, V.C. (1982) Insects and Mites of Cultivated Plants in South Africa, Butterworths, Durban.

Aquino, P., Carrion, F., Calvo, R. and Flores, D. (2001) 'Selected Maize statistics', in Pingali, P. (Ed.): CIMMYT 1999/2000 World Maize Facts and Trends, Meeting World Maize Needs, Technological Opportunities and Priorities for the Public Sector, CIMMYT, Mexico D.F.

Department of Agriculture (1991) Crop Production Guidelines for 1992/1993, Unpublished guidelines to department extension officers, South Africa.

Kfir, R. (1997) 'Natural control of the cereal stem borers Busseola fusca and Chilo partellus in South Africa', Insect Science and its Application, Vol 17, No.1, pp. 61-67.

Marra, M.C., Pardey, P.G. and Alston, J.M. (2002) 'The payoffs to agricultural biotechnology: an assessment of the evidence', Environment and Production Technology Division (EPTD), International Food Policy Research Institute (IFRPI), Washington DC, Discussion Paper No. 87.

\section{Notes}

1 Bacillus thuringiensis refers to a group of rod-shaped soil bacteria found all over the earth, that produce 'cry' proteins which are indigestible by yet still 'bind' to-specific insects' gut (i.e., 
stomach) lining receptors, so those 'cry' proteins are toxic to certain classes of insects (corn borers, corn rootworms, mosquitoes, black flies, some types of beetles, etc.), but which are harmless to all mammals. Genes that code for the production of these 'cry' proteins that are toxic to insects have been inserted by scientists since 1989 into vectors (i.e., viruses, other bacteria, and other microorganisms) in order to confer insect resistance to certain agricultural plants. Nill, K. R. (2000) Glossary of Biotechnology Terms, Second Edition, http://biotechterms.org/

2 Personal communication with Petrus Van Rooyan, Pannar Headquarters, Greytown, Republic of South Africa, August 21, 2003.

3 Farmers are required to plant $20 \%$ of their Bt area with conventional hybrids if they spray the refuge with pesticides or $5 \%$ conventional hybrids if they do not spray the refuge with pesticides.

4 Personal conversations with Jean-Luc Hofs, CIRAD, and University of Pretoria, August 14, 2003. 